\title{
AS INTERFACES DO MEIO DE COMUNICAÇÃO REVISTA COM O SUJEITO PRODUTOR, NO CENÁRIO REGIONAL: UMA ANÁLISE DA CONSTRUÇÃO DISCURSIVA E SUAS FORMAS DE EXPRESSÃO
}

\author{
Sônia Maria Moro do Nascimento ${ }^{1}$ \\ Thiago Sitoni Gonçalves ${ }^{2}$ \\ Higor Aparecido Bessani da Silva ${ }^{3}$ \\ Débora Luana Servidone ${ }^{4}$
}

NASCIMENTO, S. M. M. do; GONÇALVES, T. S.; SILVA, H. A. B. da; SERVIDONE, D. L. As interfaces do meio de comunicação revista com o sujeito produtor, no cenário regional: uma análise da construção discursiva e suas formas de expressão. EDUCERE - Revista da Educação, Umuarama, v. 19, n. 2, p. 363-391, jul./dez. 2019.

RESUMO: A presente pesquisa centrou-se na análise de materiais publicitários impressos, mais precisamente em anúncios publicitários, veiculados nas revistas produzidas em Umuarama-PR e região, no período de 2010 a 2018, a fim de verificar o potencial comunicativo das mensagens. O foco da análise são os aspectos linguísticos e semióticos, bases fundamentais para revelar o processo discursivo desse material do ponto de vista da linguagem e de suas interfaces do meio de comunicação (a mídia revista) com o sujeito produtor (o codificador da mensagem). Em relação a esses aspectos, foi analisada a dinâmica discursiva de quatro revistas produzidas em Umuarama/PR, sendo elas: Viajar é preciso; Radar Umuarama; Território Feminino; e Vitrine Concept; e uma produzida na cidade de Cianorte/PR, a revista Lar. Este estudo descreve, portanto, o perfil, tanto do ponto de vista do segmento de comunicação quanto da dinâmica discursiva de cada uma dessas revistas mencionadas e também de quatro anúncios impressos, sendo eles: Escola Satélite, Jamel, Dr. Thiago Iria e Casa Toesca.

DOI: $10.25110 /$ educere.v19i2.2019.7730

${ }^{1}$ Doutora em Comunicação e Semiótica. Docente e Pesquisadora da UNIPAR

${ }^{2}$ Acadêmico do Curso de Psicologia. Bolsista PIBIC/UNIPAR

${ }^{3}$ Acadêmico do Curso de Psicologia. Bolsista PIBIC/UNIPAR

${ }^{4}$ Acadêmica do Curso de Psicologia. Bolsista PIBIC/UNIPAR 
PALAVRAS-CHAVE: Construção Discursiva; Aspectos Linguísticos e Semióticos; Revista Impressa; Mídia Regional; Umuarama/PR.

\section{THE INTERFACES OF MAGAZINE MEDIA WITH THE PRODUCER SUBJECT IN THE REGIONAL SCENARIO: AN ANALYSIS OF DISCURSIVE CONSTRUCTION AND ITS FORMS OF EXPRESSION}

ABSTRACT: This study was based on the analysis of advertising printouts, more specifically the ones posted in magazines produced in the city of Umuarama, Paraná, and nearby towns, from 2010 to 2018, in order to verify the communicative potential of their messages. The analysis is focused on the linguistic and semiotic aspects, essential to the disclosure of the discursive process for this type of material, regarding the point of view from the language and its interfaces with the means of communication (the magazine media), along with the producer (the message codifier). Concerning these aspects, the discursive dynamic of four magazines produced in the city of Umuarama/PR was analyzed. They are: Viajar é preciso; Radar Umuarama; Território Feminino; and Vitrine Concept; as well as one magazine produced in the city of Cianorte, also in the state of Paraná: Lar. Therefore, this study describes the profile, both from the communication point of view and from the discursive dynamic of each of the aforementioned magazines, and also four printed advertisements, which are: Escola Satélite, Jamel, Dr. Thiago Iria, and Casa Toesca.

KEYWORDS: Discursive Construction; Linguistic and Semiotic Aspects; Print Magazine; Regional Media; Umuarama.

\section{LAS INTERFACES DEL MEDIO DE COMUNICACIÓN REVISTA, CON EL SUJETO PRODUCTOR, EN EL ESCENARIO REGIONAL: UN ANÁLISIS DE LA CONSTRUCCIÓN DISCURSIVA Y SUS FORMAS DE EXPRESIÓN}

RESUMEN: Esta investigación se centró en el análisis de materiales publicitarios impresos, más precisamente en anuncios publicitarios, vehiculados en revistas producidas en Umuarama-PR y región, en el periodo de 2010 a 2018, para verificar el potencial comunicativo de los mensajes. El 
enfoque del análisis fueron los aspectos lingüísticos y semióticos, bases fundamentales para revelar el proceso discursivo de ese material desde el punto de vista del lenguaje y sus interfaces del medio de comunicación (revista) con el sujeto productor (el codificador de mensajes). Con respecto a esos aspectos, se analizó la dinámica discursiva de cuatro revistas producidas en Umuarama / PR, a saber: Viajar é preciso; Radar Umuarama; Território Feminino; y Vitrine Concept; y una producida en la ciudad de Cianorte / PR, revista Lar. Por lo tanto, este estudio describe el perfil, tanto del punto de vista del segmento de comunicación como de la dinámica discursiva de cada una de esas revistas mencionadas y también de cuatro anuncios impresos, a saber: Escola Satélite, Jamel, Dr. Thiago Iria y Casa Toesca.

PALABRAS CLAVE: Construcción Discursiva; Aspectos Lingüísticos y Semióticos; Revista Impresa; Medios Regionales; Umuarama / PR.

\section{INTRODUÇÃO}

Uma pesquisa que investigou a produção de revistas locais apontou que esse foi um dos meios de comunicação que mais se desenvolveram nas últimas duas décadas na região de Umuarama-PR. O estudo revelou que a revista mais antiga produzida em Umuarama-PR data do ano de 1965. Entre 1996 e 2010, foram produzidas e lançadas nessa cidade dezessete títulos de revistas, em diferentes segmentos. (NASCIMENTO; OLIVA, 2011). Vale destacar que depois de 2010 outras revistas foram lançadas. Outro ponto que vale mencionar é o curto tempo de permanência de veiculação de algumas delas no mercado de comunicação.

O presente estudo analisou os mecanismos discursivos, e seus desdobramentos, de anúncios publicitários produzidos para veiculação na mídia revista, tanto do ponto de vista linguístico como do semiótico. Os desdobramentos dos mecanismos discursivos aqui analisados focalizam os seguintes aspectos: de linguagem das revistas como uma opção de mídia regional; as estratégias e estruturas discursivas da comunicação publicitária; a segmentação de público de uma revista; o potencial de comunicação das capas das revistas; o perfil conceitual de uma revista na construção do seu espaço publicitário; e a construção da mensagem na produção de anúncios publicitários.

Das revistas lançadas entre 2010 e 2018, foram selecionadas cin- 
co para serem analisadas. Quatro delas produzidas na cidade de Umuarama/PR, sendo elas: Viajar é preciso; Radar Umuarama; Território Feminino; e Vitrine Concept; e a outra revista, intitulada Lar, produzida na cidade de Cianorte/PR. Será apresentada uma análise do perfil de cada uma delas, focalizando os aspectos discursivos e também suas formas de expressão, em relação ao seu segmento de comunicação. Na sequência, a análise de quatro anúncios: Escola Satélite, Jamel, Dr. Thiago Iria e Casa Toesca.

\section{O MEIO DE COMUNICAÇÃO REVISTA COMO MÍDIA RE- GIONAL}

Embora novos formatos de veiculação da informação entram em cena na era digital, a revista impressa ainda é um meio de comunicação que vem se expandindo nas últimas décadas, em especial como mídia local e regional. Moreira et al. (1996, p. 292) definem revista como um "meio de comunicação e propaganda impressa, de publicação periódica, em que são divulgados artigos, reportagens e outras matérias de interesse geral ou setorial". Uma revista impressa pode ser folheada diversas vezes, e, em relação a isso, pode-se dizer que a revista não é descartável facilmente.

Segundo Sant'Anna (2001, p. 209), “a revista pode ser lida com mais vagar, e tem maior percentualidade de leitores por número". E com essas características, os anúncios publicitários nela contidos ficam em exposição por um tempo mais longo. Esse meio de comunicação, a revista, despontou na cidade de Umuarama/PR na década de 1960.

Incialmente, vale recuperar um pouco da história dos meios de comunicação em Umuarama/PR. Fundada em 25 de junho de 1955, seu primeiro veículo (oficial) de comunicação foi o jornal "A Gazeta de Umuarama", lançado em 26 de dezembro de 1961, tendo como diretor proprietário Lucio Pipino. Segundo estudos de Nascimento e Oliva (2011, p. 59), os mesmos produtores desse jornal lançaram em junho de 1965 uma edição especial de uma revista, intitulada "A Gazeta de Umuarama". Tem-se aí uma marca embrionária desse meio de comunicação nessa cidade. Mas só no ano de 1996 surgiu uma revista de periodicidade trimestral, Atualíssima, com um perfil de mostrar a sociedade umuaramense, e que esteve 
em circulação até o ano 2000. (NASCIMENTO; OLIVA, 2011, p. 62).

$\mathrm{Na}$ cidade de Umuarama/PR, essa mídia tem crescido a passos largos. Um dos fatores influenciadores para esse crescimento é a demanda de mercado. Segundo Peruzzo (2005, p. 73), "aproximadamente na segunda metade dos anos 1990, no Brasil, a mídia regional e local começa a chamar a atenção pelo interesse demonstrado pelos segmentos de públicos locais e regionais".

Entre o período de 1996 a 2010, Nascimento e Oliva (2011, p. 62) evidenciaram as seguintes produções de revistas na cidade de Umuarama/ PR: Atualíssima (1996); Personalidades em Destaque (1998); Afinal de Contas! (1999); Saúde (2004); Imagem (2006); W (2006); Metamorfose (2006); Senha (2007); Autoclasse (2009); Meu Carro (2009); Requinte (2009); Aplause (2009); Guia Umuarama (2009); Kids Mais (2009); Casa Decor (2010); Odontologia em Foco (2010); Estética e Bem-Estar (2010). Se somada toda a produção de revistas, em variados segmentos, entre 1996 a 2010, foram lançados dezessete títulos, sendo nove deles entre maio de 2009 a julho de 2010.

A partir dessa data até o ano de 2018, o presente estudo evidenciou o lançamento de treze títulos, conforme seguem mencionados: É Rodeio (2010); Acelerando (2011); Imobiliário Paraná (2014); Território Feminino (2014); Vitrine Concept (2014); Guia Automax (2015); Radar (2015); Viajar é Preciso (2015); Corpo em Forma (2015); Obra (2016); Guia Saúde Atual (2016); Seu Direito / Dr. Direito (2016); Portal Saúde (2017); Foco+ (2017); e AMU (2018).

Da lista de revistas lançadas entre 1996 a 2010, seguem em circulação regular até a data pesquisada, ano de 2018, quatro delas: Saúde, W, Kids Mais e Casa Decor. Daquelas lançadas entre 2011 e 2018, mantém-se em circulação, no formato meio impresso, as revistas: É Rodeio (2010); Território Feminino (2014); Vitrine Concept (2014); Viajar é Preciso (2015); Guia Saúde Atual (2016); Portal Saúde (2017); Foco+ (2017); e AMU (2018).

Dessas revistas pesquisadas em Umuarama/PR, foram selecionadas quatro delas, e também uma produzida na cidade de Cianorte/PR, para a análise de seus perfis discursivos, focalizando as interfaces do meio de comunicação (a mídia revista) com o sujeito produtor (o codificador da mensagem). Para a verificação do cenário da comunicação publicitária do 
ponto de vista da linguagem e seu potencial comunicativo, foram analisados quatro anúncios veiculados nessas revistas regionais.

\subsection{REVISTA VIAJAR É PRECISO: A DINÂMICA DISCURSIVA DA COMUNICAÇÃO PUBLICITÁRIA}

Dois pontos a considerar sobre a mídia revista. $\mathrm{O}$ primeiro se refere à expansão desse meio de comunicação, isto é, o crescente número de títulos lançados nas últimas décadas, sendo a maior parte deles como mídia local e regional. O segundo ponto é que, com o avanço tecnológico, esse meio de comunicação que antes era só impresso, agora se apresenta em novo formato, o digital. Este estudo observou a dinâmica do discurso da revista Viajar é preciso, e a proposta de análise centrou-se no formato impresso. A dinâmica discursiva é o entrelaçamento das linguagens verbal e visual, isto é, o conteúdo escrito e as imagens fotográficas que compõem o(s) discursos(s) da revista.

Figueiredo (2005 p. 93) esclarece que "a revista é a mídia com melhor qualidade de impressão. [...] Em geral, revistas são impressas em papel couché, que, pelo seu brilho natural, enriquecem e embelezam a imagem". Se comparadas às produções atuais de revistas produzidas em Umuarama/PR à primeira revista lançada em junho de 1965, A Gazeta de Umuarama, verifica-se a transformação ocorrida resultante das atualizadas técnicas de produção e as tecnologias avançadas.

Passadas cinco décadas, a revista Viajar é preciso é fruto dessa nova era tecnológica de produção. Lançada em julho de 2015 por Alan Denis Sobrinho, a revista tem como segmento viagens e intercâmbios. Com sede na cidade de Umuarama/PR, a produção da revista é resultante do trabalho de alguns profissionais diretamente ligados à empresa e de outros colaboradores externos. A impressão é realizada na cidade de Maringá. Sua segunda edição foi lançada em junho de 2016, com uma tiragem de 2500 exemplares e com 83 páginas, sendo oito a mais em relação à primeira edição. A distribuição é gratuita, em clínicas em geral, empresas locais e da região.

Seu conteúdo traz o cenário das viagens, no Brasil e exterior, realizadas pela sociedade umuaramense e também da região. São imagens fotográficas dos turistas tendo como plano de fundo o local visitado. 
Ancorando a imagem, segue um texto de referência sobre os viajantes e o destino da viagem. Nesse sentido, a dinâmica discursiva se constrói nesse entrelaçamento de imagem e texto, tornando o conjunto discursivo que tem um propósito informativo (quem viajou para onde), em um anúncio publicitário. Ou seja, uma divulgação da imagem pessoal, inclusive somada a imagem da atuação profissional do turista, o que no discurso publicitário equivale à projeção de uma marca.

Esta revista interrompeu sua circulação por um período depois de sua segunda edição, voltando posteriormente no final do ano de 2018 com sua terceira edição trazendo uma proposta renovada, uma delas em relação à periodicidade, mais sazonal.

\subsection{REVISTA RADAR UMUARAMA: SEGMENTAÇÃO VARIADA}

Em linhas gerais, o meio de comunicação revista se difere do jornal por ser uma publicação com outro critério de periodicidade, pelo formato e temática variados, e pelo tratamento visual (NASCIMENTO 2002, p.18). Scalzo (2004, p. 12) explica que "a revista é também um encontro entre um editor e um leitor, um contato que se estabelece um fio invisível que une um grupo de pessoas e, nesse sentido, ajuda a construir identidade, ou seja, cria identificações, dá sensação de pertencer a um determinado grupo". Essa identidade é resultado da segmentação adotada por um meio de comunicação.

Esta análise focalizou o perfil comunicativo da revista Radar Umuarama, produzida na cidade de Umuarama/PR, do ponto de vista de seu estilo de segmentação. Foram analisadas suas sete edições lançadas, considerando os seguintes aspectos: o perfil comunicativo desse meio de comunicação; a padronização gráfica; o conteúdo; a frequência e a segmentação de mercado dos anunciantes; e regularidade de conteúdos nas edições.

A revista Radar Umuarama foi lançada na cidade de Umuarama/ PR, em cinco dezembro de 2015. Como o próprio nome sugere, busca fazer uma varredura e levar informações abordando variados gêneros de conteúdo, em suas publicações. Idealizada pelo jornalista Paulo Camargo, essa revista foi até sua sexta edição uma publicação mensal. A partir de sua sétima edição, a periodicidade passou a ser bimensal. $\mathrm{O}$ número 
de páginas dessas edições variaram entre quinze a vinte. Em relação ao conteúdo publicado, tanto nas matérias quanto nos anúncios publicitários, verifica-se uma diversidade de segmentos, ou seja, não há especificidade de segmentação.

Os anunciantes são empresas públicas e privadas e profissionais de áreas variadas. Há anúncios de restaurantes, órgãos públicos, empresas de vários segmentos, como também informativos sobre horários de transporte público e hospitais de plantão em todas as suas edições. A tiragem mensal é de dois mil exemplares em média por edição publicada, impressos na Gráfica Arenito, localizada em Umuarama/PR, sendo esta um dos anunciantes da revista.

Segundo seus produtores, não há critério quanto o destaque da capa. A distribuição é gratuita, feita em estabelecimentos públicos, lojas, autarquias, instituições de ensino e outras áreas, como as clínicas médicas e odontológicas da cidade de Umuarama/PR e região.

Quanto à produção, todas as etapas são realizadas por Paulo Camargo, sendo a diagramação, a venda dos espaços, distribuição e planejamento das edições. Se comparada às outras revistas em circulação, em Umuarama/PR, verifica-se que a Radar Umuarama tem esta configuração, não se apresentar com uma segmentação específica, e sim trazer segmentos de mercado variados em uma mesma edição.

Constata-se que não há uma padronização quanto à identidade visual da própria revista, havendo assim uma mudança entre uma edição e outra. Conteúdos como horários de ônibus, receitas culinárias, e lista de hospitais de plantão, permanecem em todas as edições como conteúdo fixo.

A revista Radar Umuarama, em relação ao seu estilo de segmento, está na contramão das demais revistas produzidas nessa cidade. Pois as outras revistas expressam, como posicionamento de sua marca, um segmento de comunicação específico, isto é, para uma área mais específica de mercado.

\subsection{REVISTA LAR: UMA MÍDIA SEGMENTADA PRODUZIDA EM CIANORTE/PR}

Para ampliar a compreensão do modo como o meio de comunica- 
ção Revista articula sua linguagem no seu contexto de atuação, foi analisada uma revista produzida em Cianorte. Fundada em 26 de julho de 1953 pela companhia Melhoramento Norte do Paraná. A cidade de Cianorte começou a prosperar a partir da terra e da cultura do café (CIANORTE/ PR). Posicionou-se como uma das mais promissoras cidades do Paraná, destacando-se no segmento de confecção e moda. Conhecida como Capital do Vestuário, tornou-se o maior polo atacadista do Sul do país. Com a demanda do mercado, pelo desenvolvimento econômico, abriram-se portas para outros setores segmentados, além da moda. Esta análise centrou-se no perfil da Revista Lar, em relação ao seu segmento de comunicação.

Segundo Sampaio (2003, p. 100), “os anúncios em revistas oferecem o benefício do direcionamento preciso para muitos segmentos de consumidores". Quando se produz uma revista, define-se para quem ela vai se dirigir, ou seja, para qual público seu conteúdo será de interesse. Entre as características da mídia revista está sua segmentação de mercado. Moreira et al. (1996, p. 298) definem segmentação de mercado como "o processo de classificar clientes em grupos com necessidades, características e comportamentos diferentes".

Com base na análise dos exemplares publicados da Revista Lar, este estudo traçou o perfil dessa mídia cuja distribuição é regional, isto é, em Cianorte/PR e cidades circunvizinhas. A Revista Lar, idealizada pelo publicitário Renan Corteze, foi lançada em 11 de dezembro de 2014. A sede da revista está localizada na cidade de Cianorte/PR. Voltada para o segmento de engenharia, arquitetura, design de interiores e lifestyle (estilo de vida), essa mídia divulga anúncios de marcas, produtos e serviços de empresas locais e regionais.

A finalidade básica de um anúncio é informar, convencer, persuadir segmentos de públicos em relação à ideias, serviços ou produtos. (MOREIRA, et al., p. 32). A Revista Lar se lançou com uma periodicidade regular (quadrimestral) e uma tiragem de quatro mil exemplares, que são distribuídos gratuitamente em empresas e clínicas (saúde e beleza) da região de Cianorte/PR.

Para a produção do conteúdo dessa revista, vários profissionais e colaboradores estão envolvidos, tais como: diretor, produtor, comercial, financeiro, jornalista editor, jornalista entrevistador, jornalista colunista, revisor de texto, trend travel (colunista de viagem), fotógrafo de capa e de 
matéria, assessor psicológico, assessor de gestão de equipe, assessor gráfico, produtora de moda, designer gráfico, retouching (retoque) de capa e interno.

Em relação ao critério adotado para a produção da capa, a preferência é dada aos profissionais da área de arquitetura, a fim de conferir credibilidade e compromisso formal com o leitor. Criar critérios para construir o discurso de uma revista é um dos aspectos que contribuem para fortalecer e manter a segmentação adotada por esse meio de comunicação.

\subsection{REVISTA TERRITÓRIO FEMININO: ANÁLISE DAS CAPAS EM RELAÇÃO AOS SIGNIFICADOS INTERATIVOS NA RE- PRESENTAÇÃO DO OLHAR}

A revista impressa é um veiculo de comunicação atemporal e com maior tempo de vida, já que o leitor é quem decide quando e quantas vezes vai (re)ler. Segundo Figueiredo (2008, p. 40), a revista "é a mídia com a melhor qualidade de impressão". Resultante de um investimento técnico, gráfico e estético, as capas de revistas são o seu principal ponto de atração.

O número de revistas produzidas em Umuarama/PR tem crescido nas últimas duas décadas. Entre as revistas lançadas nos últimos anos, está a Território Feminino. Realizou-se uma análise das capas da revista Território Feminino, considerando os aspectos discursivos representados pela imagem (fotografia das modelos) fundamentando-se na gramática do design visual e a relação de interatividade.

A revista Território Feminino foi lançada na cidade de Umuara$\mathrm{ma} / \mathrm{PR}$ em junho de 2014. Com edições trimestrais, seu conteúdo aborda assuntos relacionados ao universo das mulheres. Este estudo analisou sete capas das edições já veiculadas. Das modelos que posam para a capa, seis delas são de Umuarama/PR e uma, de Cianorte/PR. O aspecto analisado é o direcionamento do olhar das modelos as quais, neste estudo, serão denominadas de atores sociais, isto é, o sistema do olhar dos atores sociais.

A gramática visual do design compreende o engendramento dos elementos visuais na composição da imagem. Essa análise se fundamenta na função de interatividade, que segundo Kress e van Leeuwen (2000 
apud PUC RIO, p. 66), há uma dupla interação, a primeira entre os próprios elementos visuais que compõem a imagem, e a segunda interação entre quem produz e quem vê. Das sete modelos, apenas uma delas não está com o olhar direcionado diretamente para o observador.

Segundo Kress e van Leeuwen (2000 apud PUC RIO, p. 67), “o observador pode depreender dessas imagens significados relacionados às crenças, ideologias e visões do mundo do produtor, e dessa forma o observador e produtor acabam por interagirem". O vínculo direto do olhar chama o observador para interagir. O olhar direto envolve o observador. Já o olhar indireto da modelo cria uma reação em que o objeto representado (a modelo) torna-se objeto de escrutínio do observador (KRESS; VAN LEEUWEN, 2000 apud PUC RIO, p. 70).

Este aspecto é um exemplo da referência conceitual deste estudo em relação à linguagem (o discurso) e suas interfaces (a revista) com o sujeito produtor (responsáveis para produção da revista). É a forma como o produtor da capa (o fotógrafo e designer) constrói o discurso, que neste caso interage como o leitor (o observador). É um diálogo que se potencializa a partir do estreitamento no ato de comunicação entre produtor e leitor.

\subsection{REVISTA VITRINE CONCEPT: PERFIL CONCEITUAL DE COMUNICAÇÃO}

A mídia revista traz consigo algumas peculiaridades, o que faz desse veículo um meio muito eficaz quando se quer alcançar um público-alvo definido. Moreira et al. (1996, p. 292) definem revista como um meio de comunicação "de publicação periódica, em que são divulgados artigos, reportagens e outras matérias de interesse geral ou setorial". O foco desta análise é a revista Vitrine Concept, apresentando o seu perfil conceitual em relação aos aspectos que envolvem a comunicação publicitária.

As revistas produzidas em Umuarama, a maioria com periodicidade trimestral, contribuíram na ampliação dos espaços publicitários, nos quais variados nichos de mercado anunciam seus produtos, serviços e marcas. Figueiredo (2005, p. 95) afirma que "a possibilidade de anunciar em revistas segmentadas, falar a língua do consumidor, demonstrar uma 
visão de mundo similar à dele é excelente para a marca e para sua relação com o seu público". É clássico o conceito de que, conforme afirma Sampaio (2003, p.100), "as revistas diferem muito seu conteúdo, algumas sendo mais voltadas para o lazer e entretenimento, outras para a informação".

Esta análise traçou o perfil conceitual da revista Vitrine Concept a fim de verificar sua linguagem. Vitrine Concept foi lançada em dezembro de 2014, e idealizada por Silvana dos Santos Cossi e Adilson Angelo Cossi. A sede da revista é em Umuarama/PR. Sua distribuição é gratuita atingindo mais de dez cidades da região, segundo informaram seus produtores. A revista também é veiculada na versão online. A tiragem é de três mil exemplares, com periodicidade trimestral.

Em relação à origem do nome da revista, seus proprietários defendem que produtos se valorizam quando estão em uma vitrine. Dessa forma, o conteúdo veiculado na revista ganha destaque, sendo esta uma forma de valorizar também os anunciantes. A revista Vitrine Concept não apresenta um segmento específico, mas sim um espaço de apresentação e exposição para segmentos variados de mercado.

Esse posicionamento fica comprovado nos espaços publicitários, cujos anúncios são dos mais variados setores mercadológicos e profissionais. São anunciados produtos, marcas, serviços, dicas, ideias, eventos de empresas locais e regionais. Segundo os produtores da revista, seguiram sugestão do Serviço Brasileiro de Apoio às Micro e Pequenas Empresas - SEBRAE, a de não segmentar a revista, a fim de ampliar a abrangência de anunciantes.

Os anúncios não seguem ordenados por setores (produtos e serviços), estão dispostos de forma aleatória para assim fugir do estereótipo de catálogo. A diagramação e impressão são serviços terceirizados, realizados por empresas locais. Em relação à capa, é uma marca conceitual da revista apresentar apenas imagens de pessoas, dispensando assim fotos de produtos ou fachadas de empresas.

\section{ANÚNCIOS PUBLICITÁRIOS IMPRESSOS: O DISCURSO EM ANÁLISE}

Tanto a Linguística quanto à Semiótica são ciências relativamen- 
te novas, tendo suas bases lançadas com estudos mais aprofundados no final do século XIX e começo do século XX. Santaella (1983, p. 15) define semiótica como "a ciência que tem por objeto de investigação todas as linguagens possíveis, ou seja, que tem por objetivo o exame dos modos de constituição de todo e qualquer fenômeno como fenômeno de produção de significação e de sentido". Já a Linguística é a ciência que tem por objeto o estudo da linguagem humana, ou seja, o estudo das línguas.

Por outro lado, Bechara (2009, p. 30) explica que "a realidade concreta da linguagem é o ato linguístico, quer dizer, é cada unidade de comunicação da linguagem humana, seja uma palavra ou uma frase". Como se vê, a Semiótica é a ciência de todas as linguagens, enquanto que a Linguística se ocupa de um dos braços da linguagem, a verbal.

Fundamentando-se nessas duas bases teóricas, este estudo analisou elementos linguísticos e visuais dos anúncios Escola Satélite, Jamel, Dr. Thiago Iria e Casa Toesca.

\subsection{SIGNOS ICÔNICOS: OS ASPECTOS QUALITATIVOS DO OBJETO REPRESENTADO}

Anúncio é uma peça publicitária veiculada pela imprensa escrita. É constituído tanto por códigos linguísticos (título, texto e slogan), como também por códigos visuais (morfológico, cromático, fotográfico e tipográfico). A relação entre esses diferentes códigos resultam em reforços persuasivos, conforme explica Carrascoza (1999, p.18).

Todos os elementos que compõem um anúncio são Signos. Para Peirce (2003, p. 74), signo é "qualquer coisa que conduz a outra coisa", ou seja, signo é uma representação, e aquilo que o signo está apto a representar é chamado de Objeto do signo. Portanto, a relação de representação que se estabelece nesse processo forma uma relação triádica: Signo, Objeto e Interpretante, seja em qualquer forma de comunicação. Os dois anúncios que se seguem é uma demonstração dessa dinâmica da linguagem nos processos de comunicação publicitária.

\subsubsection{SIGNOS ICÔNICOS NO ANÚNCIO ESCOLA SATÉLITE}

Foi realizada uma análise considerando os signos presentes no 
anúncio da Escola Satélite, veiculado na revista Território Feminino, página 78, na edição de lançamento, de junho de 2014. Essa revista é produzida em Umuarama/PR, e seu conteúdo focaliza temas e assuntos relacionados ao universo da mulher.

Sobre o anúncio analisado, ele ocupa uma página inteira do lado esquerdo da revista. $\mathrm{O}$ anunciante é uma escola que atende do berçário ao Ensino Fundamental I e II.

Figura 1: Anúncio Escola Satélite

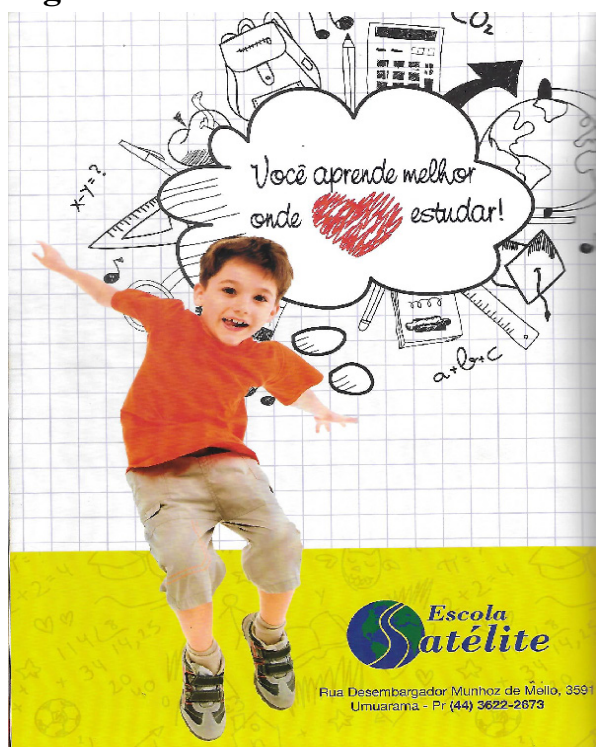

Fonte: Revista Território Feminino.

Há presentes no anúncio signos verbais e não verbais. Santaella (2004, p. 8) define signo como "qualquer coisa de qualquer espécie que representa uma outra coisa que produz um efeito interpretativo em uma mente real". Dessa forma, são signos tanto as palavras do texto quanto as imagens, a fotografia de um garoto e os desenhos figurativos.

O texto verbal que intitula o anúncio está dentro de um balão de linhas curvas assemelhando-se a uma nuvem e ponta direcional com bolinhas, o que representa "alguém pensando", como aquelas das histórias em quadrinhos. Uma das palavras da frase que forma o título foi substituí- 
da pelo desenho de um coração na cor vermelha. Esse coração é um signo que está no lugar do verbo "amar". O leitor do anúncio traduzirá a frase como: Você aprende melhor onde "ama" estudar!

Além do signo do coração, há outros desenhos figurativos. A textura visual de fundo do anúncio é quadriculada, o que se assemelha com uma folha do caderno de aritmética. Há também imagens que se assemelham com objetos escolares utilizados em aula, como: réguas, lápis, caneta, caderno, mochila, globo do mapa-múndi, lupa, capelo, notas musicais, fórmulas e cálculos matemáticos, letras do alfabeto, maçã, entre outros. A representação que se estabelece quanto ao significado de cada uma das imagens, fica no nível das aparências.

Santaella (2000, p. 120) explica que essas representações são "qualidades, tal como aparecem, nas sugestões de similaridade que despertam". Por isso, esses signos da forma como se apresentam, imagens figurativas, são signos icônicos. Conforme reitera a autora, "são as qualidades primeiras - forma, cor, textura, volume, movimento etc. - que entram em relações de similaridade e comparação, tratando-se, portanto, de similaridades na aparência”. (SANTAELLA, 2000, p. 120).

Todas essas formas são entendidas porque o leitor é capaz de estabelecer a relação entre aquilo que ele visualiza com aquele objeto real que ele conhece, pois a imagem se parece, em alguma medida, com o objeto que ela está representando.

O anúncio da Escola Satélite, uma instituição de ensino local, veiculado em uma revista impressa local, apresenta em sua composição gráfica e textual signos proeminentemente icônicos. O ícone para funcionar como signo depende das relações de similaridade, ou seja, a comparação que se faz pela aparência, que o leitor da revista estabelece com o conteúdo que ele visualiza.

A construção discursiva que se molda no anúncio Escola Satélite é resultante da composição de todos os elementos figurativos (signos) presentes no anúncio que estão aptos a gerar na mente do leitor essa identificação, a de olhar para a figura e reconhecer nela um objeto usual do universo escolar. 


\subsubsection{SIGNOS ICÔNICOS NO ANÚNCIO DE UM PROFISSIONAL DA CIRURGIA PLÁSTICA}

No anúncio de página dupla veiculado na revista Vitrine Concept, da edição de lançamento, maio de 2015, páginas 28 e 29, analisou-se os aspectos discursivos em relação à forma e ao conteúdo, estes resultantes da combinação de signos verbais (as palavras) e signos visuais (as imagens).

A página da esquerda apresenta uma imagem formada pelo retrato de nove rostos de mulheres e a seguinte frase na parte superior: "Elas já comentaram sobre as mudanças externas..."; e a da direita, a imagem de um ponto-de-interrogação com a frase "Em breve vamos perguntar sobre as mudanças internas", também na parte superior da página. Tanto a imagem dos rostos das mulheres quanto a do ponto-de-interrogação são esboços preenchidos por signos linguísticos, ou seja, palavras. A imagem dos rostos são os próprios depoimentos dessas mulheres em relação à marca anunciada, e a do ponto-de-interrogação, por inúmeros pontos-de-interrogação. $\mathrm{O}$ que se tem nessa constituição discursiva do anúncio são signos icônicos, uma forma de trazer aspectos qualitativos do objeto representando: as pacientes e uma indagação.

Figura 2: Anúncio Dr. Thiago Iria

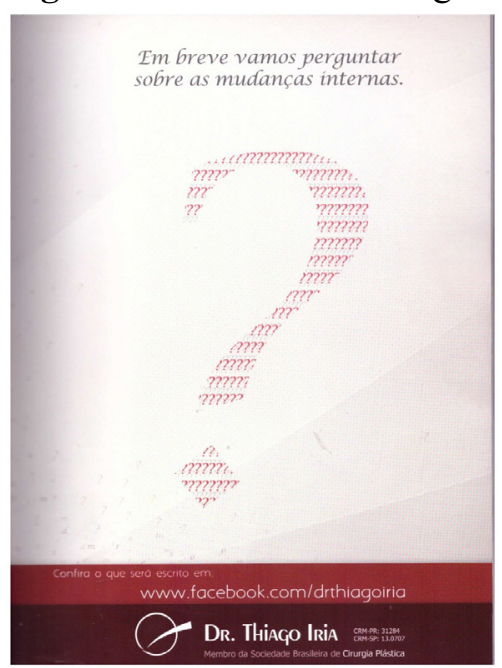

Fonte:Vitrine Concept, maio 2015, p. 28. 
Figura 3: Anúncio Dr. Thiago Iria

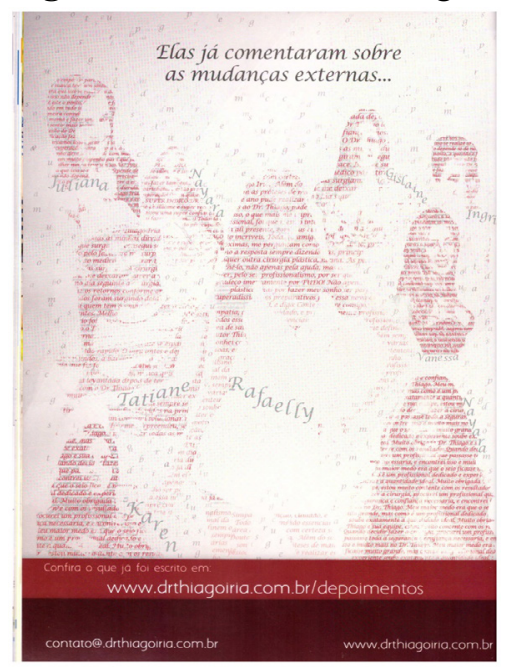

Fonte: Vitrine Concept, maio 2015, p. 29.

A construção desse anúncio é formada por dois tipos de códigos: o verbal (texto) e outro não verbal (imagens). As imagens também são constituídas por elementos verbais. Esses elementos conferem formas às imagens, rosto de mulheres e o ponto-de-interrogação. Por isso dizer que tanto as palavras quanto as imagens são signos icônicos. Conforme explica Santaella (2000, p. 111), o signo icônico se apresenta como signo porque "vem regido por relações de comparação e cuja referência ao objeto se dá por semelhança". Isso fica demonstrado nos contornos dos textos dos depoimentos que apresentam formas que se assemelham a rostos femininos.

O anúncio faz um convite ao leitor para acessar as plataformas digitais da marca, e a imagem apta a representar isso é o ponto-de-interrogação. Trata-se de algo ainda a ser respondido. Com relação a cor, pode-se perceber o emprego de cores fortes, quentes e vibrantes, há uma predominância do vermelho. Farina (1990, p.102) afirma que "as cores quentes parecem nos dar uma sensação de proximidade, calor, densidade, opacidade, secura, além de serem estimulantes". A cor vermelha é um signo icônico, que é uma qualidade apta a representar a paixão.

Esses elementos verbo-visuais (textos escritos e imagens) que 
formam retratos de faces femininas e o ponto-de-interrogação são signos icônicos porque carregam aspectos qualitativos do objeto representado. O contorno dos rostos representam as pacientes do profissional anunciante com seus referidos depoimentos, e o ponto-de-interrogação representando algo a ser buscado, que neste caso será encontrado no acesso às plataformas digitais. Este anúncio, portanto, em relação ao seu aspecto discursivo, foi predominantemente construído por signos icônicos.

\subsection{ASPECTOS LINGUÍSTICOS E SEMIÓTICOS NO ANÚNCIO JAMEL}

Realizou-se uma análise considerando os elementos sígnicos, sendo estes as palavras e as imagens, presentes no anúncio publicitário do produto Jamel, veiculado na revista É Rodeio, n. 47 de 2017. Idealizada por José Lobo e Joel Guedes, a revista foi lançada em 10 de março de 2010. Com sede na cidade de Umuarama, sua veiculação, segundo seus produtores, tem um grande alcance. São em média sete mil exemplares a cada edição (bimensal) que são distribuídos nos eventos de rodeio de diversas partes do país, eventos estes também divulgados nessa revista. Os temas que compõem seu conteúdo são referentes ao universo country.

$\mathrm{O}$ anúncio analisado ocupa a página inteira do lado direito dessa revista. Nele há presentes elementos verbais e imagens fotográficas. $\mathrm{O}$ texto verbal foi disposto no canto superior da parte lateral da esquerda da página. Seu conteúdo foi distribuído em quatro linhas, no formato estrofe de um poema. Essa estrofe está emoldurada por duas linhas horizontais paralelas, superior e inferior, com a mesma extensão das frases do texto. E para finalizar segue abaixo a última frase que se destaca em relação às outras por apresentar letras em tamanho maior.

O texto é: "Country meu estilo, / Rodeio minha paixão, / Tenho sertanejo no peito / E a viola no coração. / Tá na hora!’. Há outros elementos verbais nesse texto que são aqueles que estão no adesivo da viola, no rótulo do produto anunciado, no nome da marca e na cláusula de advertência.

Quanto aos elementos fotográficos, tem-se no cenário em segundo plano cordas, palhas, um chapéu e uma viola; e se projetando no primeiro plano está o produto anunciado, a garrafa de cachaça Jamel e outra 
imagem sobreposta que é um copo de caipirinha de limão.

Figura 4: Anúncio Jamel.

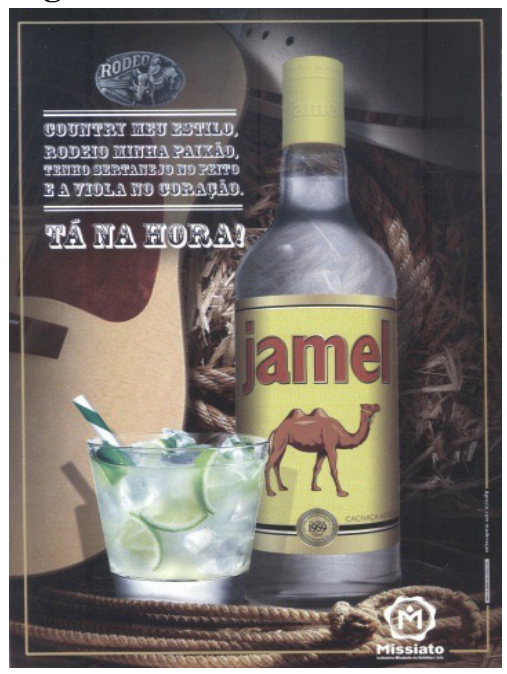

Fonte: Revista É Rodeio.

Partindo para a análise, considerando os aspectos linguísticos e semióticos, inicialmente, em relação aos aspectos linguísticos, verifica-se que o texto apresenta uma estrofe de quatro versos, sendo que no segundo e quarto versos há presença de rima pobre (paixão / coração). Bechara (2009, p. 640) define rima como sendo "a igualdade ou semelhança de sons pertencentes ao fim das palavras, a partir de sua última vogal tônica". Também, constam três figuras de linguagem na composição da estrofe.

No primeiro e segundo versos, verifica-se a elipse, ou seja, há omissão de um termo na sentença, neste caso foi omitido o verbo "é". Outra figura é o hipérbato ou inversão que, segundo Cegalla (2000, p. 576), é a alteração da ordem dos termos da frase. A inversão ocorre nos dois primeiros versos, com as palavras "Country" e "Rodeio", visto que na ordem direta estariam no final do verso. A terceira figura de linguagem é a metáfora, que ocorre no terceiro e quarto versos.

As expressões "sertanejo no peito" e "viola no coração" são metafóricas, pois representam por analogia o sentimento "amor". Andrade e Medeiros (2000, p. 287) se reportam a Aristóteles, "a metáfora consiste 
no transportar para uma coisa o nome de outra [...] por analogia". Em se tratando da frase que finaliza o texto, "Tá na hora", ela expressa de forma implícita, ou subentendida, o convite ao consumo da bebida.

Considerando o estilo discursivo, o texto verbal expressa a sonoridade e a cadência dos discursos falados por locutores de rodeio, os versos rimados. Ainda considerando os elementos verbais, há neste anúncio o aviso de "Aprecie com moderação." e "Venda proibida para menores de 18 anos.", pautado na resolução No 01./08, do Conselho Nacional de Auto-regulamentação Publicitário (BRASIL - CONAR), que permite a veiculação do anúncio em qualquer meio de comunicação, contanto que apresente a cláusula de advertência.

Partindo para o segundo aspecto da análise, o semiótico, este estudo impõe um olhar sobre a representação dos signos presentes no anúncio. Para Pierce (2003), signo é tudo aquilo que se relaciona com uma segunda coisa, ou seja, seu objeto a partir de uma qualidade vista através de seu interpretante. Em outras palavras, signo é uma representação, é uma coisa que está no lugar de outra. Logo, pode-se afirmar que os elementos textuais e fotográficos são signos, e pelo seu potencial representativo conferem significado para o anúncio publicitário.

Todos os objetos que compõem o cenário do anúncio são representações icônicas, isto é, chapéu, viola, corda e palha, são signos que representam o universo country. Sobre o produto anunciado, a imagem fotográfica de uma garrafa da cachaça Jamel e um copo de caipirinha também são signos que, no conjunto visual em que estão, eles passam a estabelecer uma representação do conceito country.

Nesta análise contata-se que o segmento da revista $E$ Rodeio (2017) é o portal de comunicação relacionado aos aspectos country, criando assim seu posicionamento de comunicação. A respeito do anúncio analisado, verifica-se a coerência discursiva do anúncio com a linguagem que o próprio veículo de comunicação tende a expressar. $\mathrm{O}$ foco discursivo do anúncio vai ao encontro da proposta da revista, que é a divulgação dos eventos country. 


\subsection{ASPECTOS INTERATIVOS NA DINÂMICA DO ANÚNCIO CASA TOESCA}

O meio de comunicação revista, em especial no cenário regional, vem adaptando a sua linguagem para atender às necessidades dos consumidores e anunciantes que dessa mídia se utilizam. Essa evolução na forma de se comunicar faz com que as páginas das revistas fiquem cada vez mais criativas, e as marcas anunciadas ganhem visibilidade. Há uma busca de interação entre revista e leitor para causar uma sensação diferenciada. Visando entender o mecanismo discursivo que essas mensagens produzem, analisou-se os aspectos interativos da linguagem presentes no anúncio Casa Toesca. Essa é uma empresa umuaramense que atua no segmento alimentício.

$\mathrm{O}$ anúncio analisado foi veiculado em página dupla na revista Kids Mais, $\mathrm{n}^{\circ} 33$, p. 91-92, 2018. Esta é uma revista produzida na cidade de Umuarama/PR. Seguem duas imagens do anúncio, e a figura 5 é a demonstração do aspecto interativo que será apontado na análise.

Figura 5: Anúncio Casa Toesca

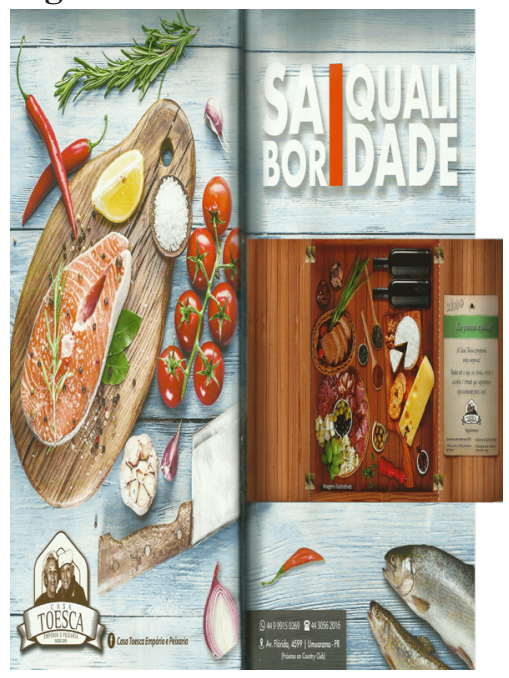

Fonte: Kids Mais. 
Figura 6: Aspecto interativo

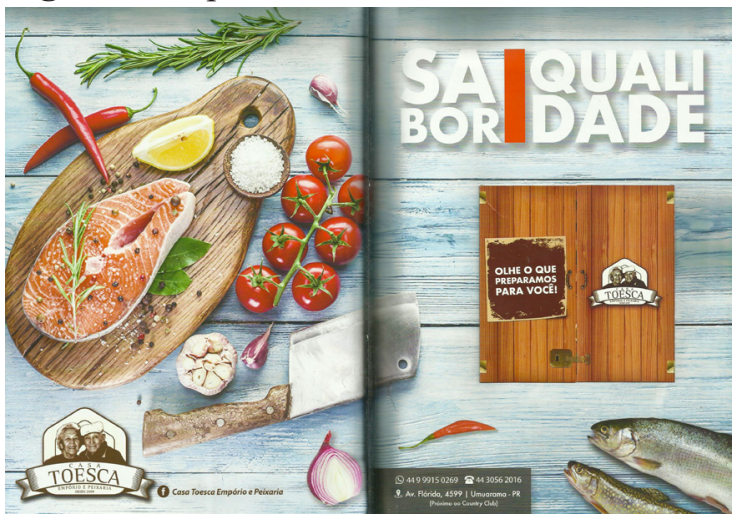

Fonte: Kids Mais, p. 92.

As bases conceituais da análise se fundamentam nos aspectos da linguagem que tratam de dois elementos dos componentes do processo de comunicação: o emissor e o receptor na sua interatividade. A acepção da palavra interação, conforme dicionário, é "ação recíproca, mútua", ou seja, é uma troca de informações, de ações, ou de outras atividades. (SILVEIRA, 2007, p. 442).

O anúncio Casa apresenta essa característica discursiva, a de propor ao leitor a interatividade. Ocupando duas páginas inteiras, lado a lado, uma textura amadeirada azul preenche todo o campo de fundo das páginas, possibilitando fazer uma associação à cor do mar e à madeira do barco, já que o principal produto desse anunciante são os peixes.

Segundo Carrascoza (2006, p. 15), a associação de ideias consiste numa forma de raciocínio em que uma ideia é ligada, mesclada ou amalgamada à outra. Do lado esquerdo há uma tábua, em um ângulo de $45^{\circ}$, com uma posta de peixe, e outros ingredientes culinários dispostos em todo o amadeirado azul.

Na página da direita, na parte superior, está escrito "sabor/qualidade". Logo abaixo do centro, há um aplique de uma janela fechada, à direta desta, a logomarca. Sobre o aplique da janela, está escrita a frase “Olhe o que preparamos para você!"”. O leitor só irá descobrir do que se trata abrindo-a. Ao abrir, é possível ver vários ingredientes culinários. Do lado direito da janela, há uma parte destacável, um convite para que 
o leitor destaque e leve ao estabelecimento para trocar por um brinde não mencionado.

De forma estratégica, além de fazer o leitor interagir com o anúncio, estimula-o a ir até o local, uma forma de promover a marca. Campos e Valle (2004, p. 47) afirmam que propagandas que chamam o leitor para a interação conseguem uma melhor assimilação, persuasão e fixação das mensagens publicitárias.

O anúncio analisado apresenta um alto nível de interatividade com o leitor, em relação ao seu aspecto discursivo. Anúncios com essas características podem gerar no receptor da mensagem uma sensação que não é gerada em uma propaganda estática veiculada em uma mídia impressa. A interatividade promove um impacto na mente do leitor, já que traz o leitor para o jogo discursivo. Dessa forma, há uma melhor fixação da marca, visto que estimula mais sentidos além da visão. Os discursos publicitários interativos fazem o leitor participar dos mesmos dependendo dele para alguma ação, o que torna o leitor não apenas um receptor passivo e sim um receptor (inter)ativo.

\section{A TRAMA DA LINGUAGEM NA CONSTRUÇÃO DISCURSIVA}

$\mathrm{Na}$ vertente semiótica peirceana, uma teoria de todas as linguagens, tudo é linguagem. Sendo assim, tudo é signo. Linguagem e signo, para Peirce (2003), são sinônimos.

O termo linguagem se estende aos sistemas aparentemente inumanos como as linguagens binárias de que as máquinas se utilizam para comunicar entre si e com os homens (a linguagem do computador, por exemplo), até tudo que, na natureza, fala ao homem e é sentido como linguagem. (SANTAELLA, 1999, p.13)

O signo é uma coisa que representa outra coisa: seu objeto. [...] o signo só pode representar seu objeto para um intérprete, e porque representa seu objeto, produz na mente desse intérprete alguma outra coisa (um signo ou quase-signo) que também está relacionado ao objeto não diretamente, nas pela mediação. 
(SANTAELLA, 1999, p. 58)

Por signo e linguagem entende-se tudo que, de alguma forma ou de alguma maneira, apresenta-se com um potencial mínimo que seja apto a significar algo. Nesse contexto das linguagens, pela sua plasticidade, elas se corporificam no meio, isto é, a linguagem ganha corpo (forma) de acordo com o meio no qual ela é veiculada.

Neste estudo, a linguagem é todo processo sígnico (dos linguísticos aos semióticos), que são as palavras, nas suas mais variadas formas e formatos de se apresentarem nas páginas, e as imagens que compõem conjuntamente o discurso construindo significados; e o meio é a revista. Vale destacar que, para a semiótica, ambos, linguagem e meio, operam como representações, por isso são processos sígnicos. O meio, mesmo tratando-se de algo físico, que é um o canal de comunicação, ainda assim esse canal é uma linguagem, é um conjunto de signos aptos a representar, em alguma medida, todo o contexto que ele, o meio, carrega consigo. A construção e articulação de elementos que compõem a mensagem revelam como a linguagem significam as coisas, conforme apontados nas análises da construção discursivas das revistas e anúncios.

Diante da análise dos aspectos da linguagem das revista como meio, como um veículo de comunicação regional, verifica-se se que no caso da revista Viajar é preciso, a imagem dos turistas protagonizando o cenário da viagem expressa um depoimento que atua como um discurso publicitário testemunhal. Um tipo de discurso validado por um sujeito que atesta a sua experiência.

A revista Radar Umuarama, assim como a anterior, é um espaço para a comunicação e a publicidade local. No entanto, seu posicionamento se distingue, por exemplo da Viajar é preciso que está direcionada potencialmente para o segmento de turismo, e também das demais analisadas, pela razão de que, enquanto as outras têm um segmento específico (saúde, lazer, design de interior, engenharia e arquitetura), a revista Radar Umuarama se revela com outra especificidade, a de ser uma revista de variedades, abrangendo vários segmentos de mercado.

Em relação à Revista Lar, ela é, na cidade de Cianorte/PR, exclusiva no segmento adotado: engenharia, arquitetura, design de interiores e lifestyle. É um veículo de comunicação cujo segmento de comunicação favorece a divulgação de uma ampla parte do mercado empresarial 
da cidade de Cianorte/PR e região. Além dos anúncios, contém matérias informativas sobre a área de referência. Trata-se de um meio de comunicação que constrói seu discurso concentrando-se nos temas de sua área de segmentação.

Diferente na sua dinâmica discursiva em relação à revista Lar, $a$ revista Vitrine Concept, por não segmentar seu público-alvo, seu conteúdo publicitário é bastante variado. Ultrapassando cem páginas a cada edição, quase que em sua totalidade, elas são anúncios publicitários, em diferentes formatos discursivos, e com abrangência de um amplo universo de anunciantes de variados segmentos, sendo eles Kids; Casa e Decoração; Mulher; Gastronomia; e Saúde. Considerando os aspectos da linguagem, conclui-se que a revista Vitrine Concept revela um posicionamento no mercado umuaramense de comunicação como uma vitrine publicitária.

Sendo essas revistas um palco para a comunicação local e regional, em especial a publicitária, são suas capas um convite ao leitor para percorrer cada uma de suas páginas. Pois é neste instante, ao ser atraído pelo espetáculo que uma capa de revista é capaz de produzir, que o leitor inicia sua experiência: a de estar diante da interface com o sujeito produtor, quem constrói o discurso. $\mathrm{O}$ primeiro vínculo já se estabelece quando o leitor visualiza a capa da revista, como foi detalhado na análise das capas da revista Território Feminino. Este é o ponto de partida de um caminho a percorrer, uma sequência de páginas que, em sua maioria , são de anúncios, uma característica muito comum das revista impressas regionais.

Em relação aos anúncios analisados, Escola Satélite, Jamel, Dr. Thiago Iria e Casa Toesca, em se tratando da construção discursiva e das formas de expressão na dinâmica de comunicação da mídia impressa "revista", a variedade de signos que compõe a mensagem (combinação texto e imagem) pode-se revelar apta a despertar interesse por parte do interlocutor, o leitor. As mensagens podem resultar com mais ou com menos eficácia comunicativa, dependendo do mecanismo discursivo nelas presentes.

A trama da linguagem é tecida pelos elementos verbais e visuais que são construções discursivas resultantes da dinâmica dos signos icônicos e também por aqueles convidam à interação. Os anúncios revelam esse potencial de se fazerem significar para além do signos verbais, ou 
seja, são mensagens cuja linguagem foi enriquecida por signos que ampliam seu universo de significação, uma característica do signo icônico, aquele que carrega uma qualidade do objeto que ele representa.

O meio e sua linguagem são partes indissociáveis. A linguagem opera no meio. $\mathrm{O}$ meio confere corpo à linguagem. Portanto, a linguagem que desenha o discurso das revistas produzidas em Umuarama e região são signos que só constroem e se revelam no meio em que estão sendo veiculado. O discurso aqui em discussão configura-se no meio revista, mais especificamente em revista regional.

\section{CONSIDERAÇÕES FINAIS}

Com o propósito de analisar a dinâmica discursiva do meio de comunicação impresso Revista, foram analisadas cinco revistas produzidas em Umuarama-PR e região, no período de 2010 a 2018, e também quatro anúncios publicitários. $\mathrm{O}$ foco de análise centrou-se na linguagem (aspectos linguísticos e semióticos) e as interfaces desse meio de comunicação com o sujeito produtor. O resultado dessa análise aponta aspectos da linguagem tanto do ponto de vista de suas características como meio impresso de comunicação regional quanto de seus processos discursivos.

Em se tratando das características do meio, analisando como uma produção dessa natureza se apresenta no conjunto de seu contexto de comunicação, pôde-se reconhecer que, independente do segmento em que se posicionam, as revistas analisadas expressam, com proeminência, um amplo cenário publicitário local. Pois são um suporte de divulgação de marcas, produtos e serviços, presentes e oferecidos, nas cidades em que esse meio é produzido.

É neste ponto, portanto, por meio de análise dos processos discursivos das revistas produzidas em Umuarama/PR e região, que o resultado desta pesquisa revela a inter-relação do território dos meios e modos de produção frente às interfaces dos meios com o sujeito produtor. É a relação que se estabelece entre quem produz (o codificador, o emissor) e quem recebe (o decodificador, o receptor) mediada pela produção (a mensagem). É nesse processo sígnico, a construção de representação, que confere às revistas produzidas na região uma característica de comunicação que lhe é própria, a possibilidade do estreito diálogo com o interlo- 
cutor.

Desde suas primeiras produções em 1996 ao crescente número de novos lançamentos, essa relação que vem se estabelecendo de longa data entre esse meio de comunicação e seus leitores ainda se revela forte. Mesmo as revistas lançadas com um histórico de curta permanência de veiculação no mercado umuaramense se somadas àquelas que se mantém com o seu rigor de circulação, são elas o retrato do que é a comunicação impressa regional.

\section{REFERÊNCIAS}

ANDRADE, M. M.; MEDEIROS, J. B. Comunicação em língua portuguesa. São Paulo: Atlas, 2000.

BECHARA, I. Moderna gramática portuguesa. Rio de Janeiro: Nova Fronteira, 2009.

BRASIL. Conar, Resolução $n^{\circ}$ 01./08 de 18 de fevereiro de 2008. Disponível em: http://www.conar.org.br/codigo/codigo.php. Acesso em: 05 ago. 2017.

CAMPOS, P. L.; VALLE, R. L. Propagandas interativas em mídia impressa. Uniara, Araraquara, n. 15, p. 43-52, 2004. Disponível em: http://www.revistarebram.com/index.php/revistauniara/article/view/305. Acesso em: 04 jul. 2018.

CARraScOZA, J. A. A evolução do texto publicitário. São Paulo: Futura, 1999.

. Redação publicitária: estudos sobre a retórica do consumo. São Paulo: Futura, 2006.

CASA TOESCA. Kids Mais, Umuarama, ano 9, n. 33, p. 90-91, mar. 2018.

CEGALLA, D. P. Novíssima gramática da língua portuguesa. 43 ed. São Paulo: Nacional, 2000. 
CIANORTE/PR. Prefeitura Municipal. História: a cidade que se redescobriu e se tornou a capital nacional do vestuário. Disponível em: http://www.cianorte.pr.gov.br/a-cidade/sobre-cianorte/historia/. Acesso em: 02 ago. 2016.

DR. THIGO IRIA. Vitrine Concept, Umuarama, ano 1, n. 1, p. 28-29, maio, 2015.

FARINA, M. Psicodinâmica das cores em comunicação. 4. ed. São Paulo: Edgar Blucher, 1990.

ESCOLA SATÉLITE. Território Feminino, Umuarama, ano 1, n. 1, p. 78 , jun. 2014.

FIGUEIREDO, C. Redação publicitária. São Paulo: Pioneira Thomson Learning, 2005.

JAMEL. É Rodeio, Umuarama, ano 7, n. 47, 2017.

MOREIRA, J. C. T. et al. Dicionário de termos de marketing. São Paulo: Atlas, 1996.

NASCIMENTO, C. P. Jornalismo em revista no Brasil: um estudo das construções discursivas em Veja e Manchete. São Paulo: Annablume, 2002.

NASCIMENTO, S. M. M.; OLIVA, R. A mídia revista em Umuarama/ PR: memória e publicidade. Akrópolis, Umuarama, v. 19, n. 1, p. 57-70, jan./mar. 2011.

PERUZZO, C. M. K. Mídia regional e local: aspectos conceituais e tendências. Comunicação e Sociedade. São Bernardo do Campo: Póscom-Umesp, a. 26, n. 43, p. 67-84, jan./jun. 2005. Disponível em: https://www.metodista.br/revistas/revistas-ims/index.php/CSO/article/ view/8637/6170. Acesso em: 01 ago. 2016.

PIERCE, C. S. Semiótica. São Paulo: Perspectiva, 2003. 
PUC RIO. Certificação digital $n^{\circ}$ 0510557/CA. Gramática sistêmicofuncional e gramática do design visual. Disponível em: https://www. maxwell.vrac.puc-rio.br/10597/10597_5.PDF. Acesso em: 03 ago. 2016.

SAMPAIO, R. Propaganda de A a Z. Rio de Janeiro: Elsevier: 2003.

SANTAELLA, L. O que é semiótica. São Paulo: Brasiliense, 1983.

. A teoria geral dos signos. São Paulo: Pioneira Thomson Learning, 2000.

. Semiótica aplicada. Pioneira Thomson Learning, 2004.

SANT'ANNA, A. Redação publicitária: teoria, técnica e prática. São Paulo: Pioneira, 2001.

SCALZO, M. Jornalismo de revista. São Paulo: Contexto, 2004.

SILVEIRA, B. Minidicionário da língua portuguesa. 2. ed. São Paulo: FTD, 2007.

Recebido em: 30/04/2019 Aprovado em: 26/08/19 